\title{
Counteracting Animal Homelessness and Providing Care for Stray Animals as a Task of a Commune
}

\section{Przeciwdziałanie bezdomności zwierząt i opieka nad zwierzętami bezdomnymi jako zadanie własne gminy}

\author{
http://dx.doi.org/10.12775/PYEL.2016.006
}

\begin{abstract}
The analysis of the Polish binding law acts allows one to assume that, on normative level, the obligation of public administration to provide care for stray animals is deeply embedded. Both the Animal Protection Act, as well as the Act on Maintaining Cleanliness, indicate the tasks of a commune in the scope of providing care for stray animals, catching homeless animals and counteracting their homelessness. Simultaneously, the analysis of jurisdiction, and inquiries as well as considerations emerging in practice of law, questions the effectiveness of applied legal solutions.
\end{abstract}

* Doctor of Laws Environmental Law Protection Department, Faculty of Law and Administration of Nicolaus Copernicus University in Torun, Poland. 
Małgorzata Szalewska

\section{Keywords:}

Counteracting Animal Homelessness; Providing Care for Stray Animals; Task of a Commune.

\section{Streszczenie}

Analiza obowiązujących w Polsce przepisów prawa pozwala przyjąć,iż w płaszczyźnie normatywnej obowiązek administracji publicznej opieki nad bezdomnymi zwierzętami posiada silne umocowanie prawne. Zarówno ustawa o ochronie zwierząt, jak i ustawa o utrzymaniu czystości, w sposób jednoznaczny wskazuje na zadania gminy z zakresu opieki nad bezdomnymi zwierzętami, wyłapywania bezdomnych zwierząt oraz zapobiegania ich bezdomności. Jednocześnie analiza orzecznictwa sądowego oraz pojawiające się w praktyce pytania i wątpliwości stawiają pod znakiem zapytania skuteczność i efektywność przyjętych rozwiązań prawnych.

\section{Słowa kluczowe:}

Przeciwdziałanie bezdomności zwierząt; opieka nad zwierzętami bezdomnymi: zadania gminy.

\section{Introduction}

Technological advance and constantly changing attitude of a contemporary man towards the surrounding reality constitutes one of the ground factors shaping the currently binding law regulations, including, in particular, regulations of public law. Deeply embedded in the Western culture is the idea of humanitarian treatment of animals, which being a mark of civilization progress, sets a wide range of administrative and legal regulations of animal caretaking and protection ${ }^{1}$. Actions undertaken by our ancestors thousands of years ago which led to domestication of some animals and their incorpo-

1 A. Nałęcz, Ochrona zwierzq̨ a postęp cywilizacyjny, in: Wptyw przemian cywilizacyjnych na prawo administracyjne i administracje publiczna, eds J. Zimmermann, P.J. Suwaj, Warszawa 2013, p. 673. 
ration into man-serving production processes were the source of contemporary obligation of a man to provide care and appropriate living conditions for those species. Basic legal mechanism of obtaining socially desired results is a system of commandments and prohibitions addressed to those taking care of animals. What seems to be indispensible in the contemporary world is also an institutional system which guarantees humanitarian treatment of animals, in particular those dependable on a man, regardless of the degree of realization of moral, social and legal obligations by those obliged to provide care. In this aspect a need to create an effective system of providing care for stray animals and counteracting animal homelessness takes on a special meaning.

\section{Normative basis}

Legal act which establishes obligations of a commune in the aspect of counteracting animal homelessness and proving care for stray animals is the Animal Protection Act of 21 August 19972. A supplementary act defining, amongst other, rules of maintaining animal shelters is the Act of 11 March 2004 on Animal Health Protection and Fighting against Infectious Animal Diseases ${ }^{3}$. Settled on the base of the Animal Protection Act was the idea that an animal as a living being, and not an object, is capable of feeling pain. Regulations relating to animals as objects are binding only and exclusively within a scope which is not regulated by the provisions of the Animal Protection Act. Simultaneously Legislator expressis verbis indicates that a man owes an animal respect, care and protection, and public administration bodies are obliged to take actions in aid of animal protection cooperating in this scope with appropriate foreign and state institutions and organizations. On the ground of the Polish Law, the Animal Protection Act constitutes a normative act relating to, the so called, humanitarian

2 Journal of Laws 2013 item 856, with further amendments, hereinafter referred to as the Animal Protection Act, or abbreviated to 'APA'.

3 Journal of Laws of 2014 item 1539, with further amendments, hereinafter referred to as the Act on Animal Health Protection, or abbreviated to 'AAHP'. 
animal protection ${ }^{4}$. The principle of humanitarian animal protection was explicitly stated by article 5 of APA, according to which 'every animal requires humanitarian treatment'. The notion of humanitarian treatment of animals is a legal notion which definition was formed in article 4 item 2 of APA, as a treatment taking into consideration need of animals and, providing animal with care and protection. In the literature on the subject matter it is indicated that a norm of article 5 of APA states different scope of obligations, depending on the relationship between an interested party and an animal. In case of people taking care of them, the humanitarian treatment would mean active obligations of providing feeding, shelter, medical care and appropriate living conditions. Whereas in case of other people, humanitarian treatment would mean a passive approach, including restraining from non-humanitarian behaviour, which is detailed in article 6 of $\mathrm{APA}^{5}$. Applied differentiation of scopes of obligations acceptable in typical situations of providing animal care by its owner or other person acting on behalf of an owner, loses its meaning when a person obliged to provide care and protection fails to perform it, especially, when an animal is homeless. It should be assumed that the rule of obligation of humanitarian treatment of animal constitutes a source of duties of a state to take on such instruments which would guarantee that every animal, including homeless one, is provided with appropriate care. On the grounds of the Animal Protection Act, a legal provision relating to the above-mentioned duty of the state is article 11 of APA, according to which providing care for stray animals, including their catching, belongs to tasks of a commune. Moreover, according to article 3 item 1 of the Act on Maintaining Cleanliness ${ }^{6}$, maintaining cleanliness and order in communes lies in the obligation scope of tasks of a commune itself. One of the listed obligations is counteracting animals' homelessness on the grounds sets by the Animal Protection Act. Tasks of a commune are public tasks aiming

\footnotetext{
4 On the subject of humanitarian animal protection: E. Smaga, Ochrona bumanitarna zwierzat, Białystok 2010, and J. Białocerkiewicz, Status prawny zwierzat. Prawa zwierząt czy prawna ochrona zwierzq̨, Toruń 2005.

5 W. Radecki, Ustawa o ochronie zwierząt. Komentarz, Warszawa 2012, p. 63.

6 Act of 13 September 1996 on Maintaining Cleanliness and Order in Communes, Journal of Laws of 2016 item 250, with further amendments, hereinafter referred to as Act on Maintaining Cleanliness, or abbreviated to 'AMC'.
} 
at fulfilling the needs of a self-governed community ${ }^{7}$. A catalogue of tasks of a commune, as a basic unit of territorial self-government in Poland, is defined by article 7 of the Act on Commune Self-government ${ }^{8}$, whereas the catalogue is open ended. The analysis of the text allows one to presume that Legislator, on the level of the Act on Commune Self-government, does not directly indicate commune's obligations in the scope of providing care for stray animals, doing it only on the level of detailed regulation. Placing the provisions of commune's obligations in the scope of providing care for stray animals in the Animal Protection Act allows one to presume that the fundamental goal of exercising those obligations is animal protection, including humanitarian treatment, whereas secondary goal is a guarantee of security and public order.

Determining the scope of subject task of providing care for stray animals, the definition of a homeless animal should be referenced to first of all. The definition is set by Legislator by article 4 item 16 of APA, and states it is a domestic and farm animal which run away, got lost or was abandoned by its owner, and there is no possibility to identify its owner or a person acting on behalf on an owner. Meaning that to determine the scope of the definition of a stray animal it is essential to determine a combination of the criteria: 1) classifying an animal as a domestic or farm animal, 2) determining that an animal run away, got lost or was abandoned by a man, 3) lack of possibility to identify its owner or a person acting on behalf on an owner. According to article 4 item 17 of APA, domestic animals are animals traditionally staying with a man in their house or any other similar accommodation, provided for by a man as their companion. In its judgment of 29 April 2009, the Supreme Administrative Court in Warsaw stated that in a common language 'domestic animals are the ones kept at home by a man for their personal pleasure, as opposed to animals kept or bred for different reasons (livestock, farm animal and working animal). Domestic animal is an animal which is kept at home or apartment to fulfil emotional needs of a man, as an animal accompanying a man, or as a form of decoration or attraction. Domestic animal is usually treated by household members as a favourite or family member. A favourite is most commonly defined as an individual

7 Act of 2 April 1997 Constitution of the Republic of Poland, Journal of Laws of 1997 No. 78, item 483, with further amendments.

8 Act of 8 March 1990 on Commune Self-government, Journal of Laws of 2016 item 446, with further amendments. 
that is liked more than other individuals of the same species, but being also a charge or fosterling. The same species (e.g. domestic pig) can be a livestock (kept for its meat, and bred for further reproduction), or a domestic animal. A dog kept in a fenced terrain which it is supposed to protect, is a working animal. Kept on a farm, it still holds a working, utility role. It becomes a domestic animal when an emotional bond is set between a man and an animal, and when an animal is granted a right to reside with people as a member of a horde' ${ }^{\prime}$. Manner of determining the definition of domestic animal proposed by an administrative court relates to a tool classifying a specified animal in a specified factual situation to a group of domestic animals. However, a definition stated in article 4 item 17 of APA, especially in the context of commune's obligation to provide care for stray animals, serves, above all, to point out in genere animal species designated by the definition. Legislator underlines the criterion of 'traditional' residing with a man, being provided by a man, and the special nature of man - animal relation depicted in the notion of a man's companion. Defining a notion of farm animals Legislator, in article 4 item 18, applied a special legislative technique of referring to a different legal act. According to this regulation, a farm animal is as a farm animal within the meaning of provisions of the Act on Organization of Animal Breeding and Reproduction ${ }^{10}$. The definition of farm animal sets by the above-mentioned act enumerates categorizes of animals considered by Legislator as farm animals. According to article 2 item 1 of AABR, farm animals are: a) equidae - animals of species: horse (Equus caballus) and donkey (Equus asinus), b) cattle - animals of species: cow (Bos taurus) and water buffalo (Bubalus bubalus), c) cervidae - animals of species: red deer (Cervus elaphus), sika deer (Cervus nippon) and fallow deer (Dama dama) kept in a fram-like conditions for meat and skin, if coming from a closed breeding, stipulated by provisions of game law, or farm breeding, d) poultry ${ }^{11}$, e) wild boar (Sus scrofa), f) sheep (Ovis aries), g) domestic goat (Capra hircus), h) western honey bee (Apis mellifera),

9 Judgement of Supreme Administrative Court in Warszawa of 29 April 2009, II OSK 1953/08, CBOSA.

10 Act of 29 June 2007 on the Organization of Animal Breeding and Reproduction, Journal of Laws No. 133, item 921, with further amendments, hereinafter referred to as the Act on Animal Breeding, or abbreviated to 'AABR'.

11 Understood by Legislator as poultry are the following species: red junglefowl (Gallus gallus), mallard (Anas platyrhynchos), Muscovy duck (Cairina moschata), grayleg goose (Anser anser), swan goose (Anser cygnoides), wild turkey (Meleagris gallopavo), Japanese 
i) fur-bearing animals ${ }^{12}$. The method of defining farm animals applied by Legislator based on positive enumeration results in a situation where animals not listed in article 2 item 1 of AABR are not considered as farm animals within the meaning of provisions of the Act on Animal Breeding, and in connection to article 4 item 18 of APA are not considered as farm animals within the meaning of provisions of the Animal Protection Act. In its judgment of 12 May 2010, Voivodeship Administrative Court in Warsaw ruled that although breeding of dog breeds is treated as a special division of agriculture, it does not mean that a dog should be treated as a farm animal ${ }^{13}$. The third categories of animals defined by the Animal Protection Act are free-living animals, wild animals, including non-domesticated animals living in conditions independent from a man. Applied by Legislator division of animals into domestic, farm and free-living ones is open ended. Applied by Legislator system of classifying criteria results in situations where there is no possibility of classifying an animals into any statutory category, an example of which is homing pigeon, which in the assessment of courts is not a domestic animal, nor a farm one ${ }^{14}$, and in the same time does not meet the statutory criteria to be classified as a free-living animal. In light of the above stated, it can be assumed that the task of providing care for homeless animals, stipulated by article 11 of APA, relates only to domestic and farm animals, within the meaning the Animal Protection Act. It means that the task excludes providing care for free-living animals, or animals which according to definition applied by Legislator do not fit the categories of domestic and farm animals (e.g. abandoned breeding of pigeons). Prerequisite for classifying an animal as homeless is determining that an animal is lost, has run away or has been abandoned by a man. In specified

quail (Coturnix japonica), helmeted guineafowl (Numida meleagris), and kept in ferm-like conditions ostrich (Struthio camelus).

12 Understood by Legislator as fur-bearing animals are the following species: red fox (Vulpes vulpes), Arctic fox (Alopex lagopus), American mink (Mustela vison), European polecat (Mustela putorius), raccoon dog (Nyctereutes procyonoides), coypu (Myocastor coypus), long-tailed chinchilla (Chinchilla lanigera) i European rabbit (Oryctolagus cuniculus), kept for raw material for fur, meat and textile industries.

13 IV SA/Wa 346/10, CBOSA.

14 Judgement of Supreme Administrative Court in Warszawa of 18 February 2014, II OSK 2746/1, CBOSA, Judgement of Supreme Administrative Court in Warszawa of 8 November 2012, II OSK 2023/12, CBOSA, Judgement of Supreme Administrative Court in Warszawa of 29 April 2009, II OSK 1953/08, CBOSA. 
factual circumstances differentiating between these situations would pose a difficulty of practical nature. In my opinion the core of this condition, in a particular case, is not determining whether an animal is lost, has run away or has been abandoned, but rather whether it is in a situation where factual circumstances implied by the analysed regulation apply (e.g. an animal stays without care, strays, is malnourished and/or dehydrated, etc.). Moreover, to acknowledge the existence of the state of animal homelessness, Legislator requires a lack of possibility to identify its owner or a person acting on behalf on an owner. It means that a condition of acknowledging an animal as homeless is taking active, but ineffective actions of identifying its foregoing caregiver.

According to article 11 item 1 of APA, tasks of a commune relating to stray animals are defined as providing care for homeless animals, and their catching. Moreover, article 3 item 2 point 14 of AMC imposes on a commune an obligation to counteract animal homelessness as one of the elements of maintaining cleanliness and order within its borders.

\section{Programme of providing care for stray animals and counteracting animal homelessness}

Exercising tasks of a commune in the scope of providing care for homeless animals should be of continuous and organized nature. Due to this, Legislator imposes on commune bodies an obligation to establish an annual programme of providing care for stray animals and counteracting animal homelessness. According to article 11a of APA, passing of the programme is conducted by a commune council, till 31 March of every year. Programme is mandatory, and its content, as stipulated by article 11a item 2 of APA, is to guarantee the execution of obligations imposed on a commune and stipulated by article 11 item 1 of APA. In the literature on the subject matter it is correctly indicated that, a natura rei, the programme serves to plan forms and manners of exercising actions in aid of homeless animal protection within its validity period ${ }^{15}$. According to M. Stahl, 'the core

15 K. Wlaźlak, Funkcja planowania gminy na przykładzie programu opieki nad zwierzętami bezdomnymi oraz zapobiegania bezdomności zwierząt, Przegląd Prawa Publicznego 2015, No. 4, p. 45. 
of planning is an analysis of the existing state and prediction of further development, necessary due to the need of rationale and effective action, and plans constitutes a full making concept, vision of appreciation, harmonizing different interest, and coordinating actions of different ${ }^{16}$. Qualifying particular form of administrative action to category of planning acts does not permanently judges on the legal nature of this act, particularly in the scope of commonness of its applicability. One of the key controversies which emerge in the field of assessment of legal nature of commune programme of providing care for stray animals and counteracting animal homelessness is determining the scope of commonness of its applicability. Both in jurisdiction and doctrine, different ideas are presented. On one hand, it is indicated that programme is just an internal management act addressed to commune bodies and dependable subjects, and by that is not a commune public legal act ${ }^{17}$. On the other hand, contrary opinions are presented classifying that programme as a normative act commonly binding - a commune public legal act ${ }^{18}$.

According to article 11a item 2 of APA, programme includes: 1) guarantee of places in a shelter for stray animals, 2) caretaking over free-living cats, including their feeding, 3) catching homeless animals, 4) mandatory sterilization or castration of sheltered animals, 5) searching for new owners for homeless animals, 6) putting down blind litter, 7) indicating a farm to provide place for farm animals, 8) providing round-the-clock veterinarian care in cases of transport accidents involving animals. Moreover, according to article 11a item 5 of APA, the programme

16 M. Stahl, Szczególne prawne formy dziatania administracji, in: R. Hauser, Z. Niewiadomski, A. Wróbel, System prawa administracyjnego, vol. 5, Prawne formy dziatania administracji, Warszawa 2013 p. 366.

17 W. Radecki, Utrzymanie czystości i porzqdku w gminach. Komentarz, Warszawa 2012, p. 113, K. Wlaźlak, op. cit., p. 38, Judgment of Voivodeship Administrative Court in Bydgoszcz of 19 November 2013, II SA/Bd 887/13, CBOSA, Judgment of 12 May 2010, Voivodeship Administrative Court in Wrocław of 26 June 2014, II SA/Wr 410/14, CBOSA, Judgment of Voivodeship Administrative Court in Bydgoszcz of 1 September 2015, II SA/ Bd 729/15, CBOSA.

$18 \mathrm{~J}$. Bobrowicz, Kwalifikacja aktu normatywnego jako aktu prawa miejscowego - na przyktadzie uchwaty w sprawie programu opieki nad zwierzętami bezdomnymi i zapobiegania bezdomności zwierzat, Administracja. Teoria-Dydaktyka-Praktyka 2012, No. 4, p. 44, Judgment of Voivodeship Administrative Court in Opole of 16 September 2014, II SA/Op 335/14, CBOSA, Judgment of Voivodeship Administrative Court in Kraków of 3 December 2013, II SA/Kr 852/13, CBOSA. 
includes implication of financial amount dedicated to its realization, and the manner of spending the amount. Apart from mandatory elements of the programme stipulated by article 11a item 2 and 5 of APA, it can be supplemented by non-obligatory plan of marking animals in commune. Such a formed structure of the programme causes that annually approved programme has to include all elements stipulated by article 11a item 2 and 5 of APA, and exclusion of any one of the elements results in defectiveness of the passed decree, and consequently, in its declaration null and void by a supervisory body or administrative court. Simultaneously, a catalogue of issues subject to regulation under the programme of providing care for stray animals is close ended, which results in lack of authority of a commune council to include other content not enumerated in article 11a item 2, 3 and 5 of APA. The programme of providing care for animals constitutes an executive act in relation to the Animal Protection Act. Its core is the adoption of unambiguous, detailed and specific deciding on the scope of issues stipulated by article $11 \mathrm{a}$ item 2 of APA, taking into account local conditioning and needs of a commune. The programme ought to be formed in such a way to constitute a base for specified actions of specific organizational bodies of a commune taken in the field of providing care for star animals and counteracting their homelessness. Purpose interpretation of provision of article 11a of APA, which should be interpreted in its relation to article 11 of APA, leads to a conclusion that for effective execution of tasks of a commune to provide care for homeless animals and their catching, it is rightful to specifically define manner of execution of those tasks. Hence, a decree passed on the grounds of article 11a of APA, ought to include elements stipulated by article $11 \mathrm{a}$ item 2 points 1-8 of APA, as obligatory and with specified content. Moreover, it ought to provide guidance of conduct in specified situations, indicate bodies responsible for executions of particular tasks, and a manner and source of funding according to article $11 \mathrm{a}$ item 5 of $\mathrm{APA}^{19}$. The degree to which the programme ought to be detailed constitutes one of the most frequent reasons of questioning by administrative courts the compliance of passed commune decrees with law. What is highlighted in jurisdiction is: obligation to indicate a particular shelter and particular farm which would provide place for

19 Judgment of Voivodeship Administrative Court in Opole of 31 July 2014, II SA/Op $325 / 14$, CBOSA. 
animal $s^{20}$, indication of a particular establishment providing round-theclock veterinarian care in cases of transport accidents involving animals ${ }^{21}$, detailed regulations regarding manner of conduct with caught animals ${ }^{22}$.

A draft of the programme is prepared by commune head (mayor), and till February 1, at the latest, is sent for opinion to: county doctor of veterinary medicine, 2) social organizations, which statutory aim is protection of animals within commune borders, 3) lessees and administrators of hunting districts within commune borders. Sending the draft for opinion is a mandatory step and is decisive as to the accuracy of procedure of passing a decree. In case of not complying with this obligation, a passed decree can be considered invalid. An opinion of a cooperating body is the weakest form of cooperation and, as in principle, is not binding, unless the provisions of law states otherwise ${ }^{23}$. As S. Biernat notices, the aim of such a form of cooperation is widening one party's knowledge on the subject, enriching a perspective by gaining a fresh look of a consulting party on the subject ${ }^{24}$. The opinion, if due to particular law regulation is not of a different character, is just an assessment of state of facts with the use of statutory or subjective criteria by the opinion giver, which is not binding for a decision making body, but a decision making body is obliged to consider the opinion and conduct its assessment ${ }^{25}$. Subjects stipulated in article 11a item 7 of APA ought to express their opinion within 21 days of receiving the draft. Not issuing the opinion within this timeframe is considered as acceptance of the programme.

20 Judgement of Supreme Administrative Court in Warszawa of 27 October 2011, II OSK 1667/11, CBOSA.

21 Judgment of Voivodeship Administrative Court in Poznań of 12 September 2014, II SA/Po 593/14, CBOSA.

22 Judgement of Supreme Administrative Court in Warszawa of 6 March 2012, II OSK 2622/11, CBOSA, Judgment of Voivodeship Administrative Court in Kielce of 29 May 2012, II SA/Ke 249/12, CBOSA.

${ }^{23}$ Example of such case is e.g. issuing positive resolution in administrative issue on condition that cooperation party issues positive opinion. Cf. article 18 item 3a of Act of 26 October 1982 on Upbringing in Sobriety and Counteracting Alcoholism, Journal of Laws of 2016 item 487.

24 S. Biernat, Dziatania wspólne w administracji państwowej, Ossolineum 1979., p. 81.

25 Judgement of Supreme Administrative Court in Kraków on 1 December 2003, II SA/ Kr 1490/01, Judgment of Voivodeship Administrative Court in Olsztyn on 7 March 2012, II SA/O1 79/12. 


\section{Catching homeless animals}

Catching homeless animals is a statutory task of a commune which is expressis verbis indicated by Legislator in article 11 item 1 of APA. It should be highlighted that, the scope of this obligation, Legislator uses two separate terms which are not differentiated as to their meaning, which indicates their synonymic character. This state ought to be considered a solecism in terms of legislative technique, and unification of accepted term ought to be posited. According to article 11 item 3 of APA it is forbidden to catch homeless animals without granting them a place in a shelter, unless that animal poses a danger to people or other animals. Catching of homeless animals only takes place according to the programme of providing care for stray animals, which mandatorily outlines detailed rules of animal catching. In light of the passed regulation, it is unacceptable for a commune council, to pass a different decree on animal catching other than the programme ${ }^{26}$. Simultaneously, the regulation states an obligation of a commune to provide place in a shelter for caught animals. To make the regulation detailed, the commune programme of providing care for stray animals has to indicate a particular shelter to which animals are to be taken. Detailed rules of catching homeless animals are stipulated in the Regulation of the Minister of Internal Affairs and Administration of 26 August 1998 on rules and conditions for catching stray animals ${ }^{27}$. According to the regulation, catching stray animals is of constant or periodic character, depending on the stipulations of the programme of providing care for stray animals. A commune body publishes, in a matter commonly acceptable in a region, at least 21 days before a planned dated of catching homeless animals: 1) date of catching, 2) borders of the territory of catching 3) address of a shelter to which caught animals are to be transported, 4) a party conducting the catching. Actions taken in regards to catching stray animals, particularly dogs and cats, include: 1 ) conducting catching by an entity with which a commune has entered into a contract, 2) transporting and placing animals in a shelter. Actions taken in regards to catching stray animals can

26 Judgment of Voivodeship Administrative Court in Kielce on 29 May 2012, II SA/ Ke 249/12, CBOSA, Judgment of Voivodeship Administrative Court in Szczecin on 28 November 2013, II SA/Sz 612/13, CBOSA.

27 Journal of Laws No. 116, item 753, hereinafter called executive order. 
be conducted by commune organizational bodies or by third party entities on the base of a signed contract. A contract can be entered into with a body running a shelter or other entity which holds appropriate permission. According to $\S 6$ of the decree, after being caught, stray animals should be immediately transported to a shelter or other temporary location for caught stray animals stipulated in a contract.

\section{Rationing of economic activity in the scope of providing care for stray animals and running animal shelters}

Economic activity in the scope of providing care for stray animals and running animal shelters is an activity subject to rationing which can only be undertaken on the base of a permission issued by a public administration body. Legal grounds for obligation of obtaining the permission is stipulated by article 7 item 1 of AMC, according to which it is mandatory for an entity to obtain the permission to conduct the following activities: providing care for stray animals and running animals shelters, pet/animal commentaries, pet/animal crematories. The permission is granted by means of a decision by a commune head or mayor of a territory of provided services. Entities discharged from the obligation of obtaining the permission are commune organizational bodies operating within the borders of its own commune and conducting activities listed in article 7 item 1 item 3 and 4 of AMC, however they are still obliged to fulfill all conditions required for granting the permission. According to article 7 item 3 of AMC, a commune council states by means of a decree, the requirements necessary to be fulfilled by an entity applying for the permission stipulated by article 7 item 1 point 3 and 4 of AMC. As indicated in jurisdiction, article 7 item 3 of AMC does not allow assuming that commune council is only entitled to introduce regulations regarding confirmation of fulfilling requirements stipulated by that law regulation. Requirements stipulated by article 7 item 3 of AMC are to be understood as requirements relating just to an entity (a contractor), and not to its conduct in front of public administration body during an on-going procedure leading to issuing the decision (permission). Taking into account that directives for content of a decree passed based on article 7 item 3 of AMC, are not precisely detailed, a commune council can set 
requirements for entities applying for the permission and demand no criminal records for crimes committed against animals ${ }^{28}$. What should be also highlighted is that commune council has competence only in relation to requirements which are to be fulfilled while applying for the permission. Commune council does not have competence in relation to requirements for conducting economic activity after obtaining the permission ${ }^{29}$. The decree passed based on article 7 item 3 of AMC is a commune public legal act. It contains abstract and general norms addressed to those outside of a public administration structure. Placing commune public legal acts in a structure of generally binding law imposes on a commune an obligation of its compliance with other generally binding law regulations. Needed to be indicated is that a legal definition of a shelter for stray animals is stipulated in article 4 item 25 of APA, according to which a shelter for stray animals is a place intended to provide care for domestic animals which comply with requirements stipulated by the Animal Protection Act. According to the Act, running a shelter for stray animals is considered an economic activity subject to regulation. A supervisory body is a county veterinary inspector. According to article 1 point 1 letter $\mathrm{j}$ of AAHP, the Act itself states veterinary requirements for undertaking and conducting activities in the scope of running animal shelter. Undertaking such activity requires handing in to a county doctor of veterinary medicine a written notification of the planned activity. After receiving such notification, a county doctor of veterinary medicine, issues a decision on assigning identification number to an entity conducting regulated activity. According to article 8 item 1 of AAHP, in case of identifying that animal shelter is being run with a breach of veterinary requirements stipulated for that kind of economic activity, and depending on the scale of danger to which the public health is exposed, a county doctor of veterinary medicine issues a decision: 1) ordering an elimination of any breaches within a limited period of time, or 2) ordering a cease of activity until all breaches are eliminated. The executive act in relation to AAHP is the Regulation of the Minister of Agriculture and

28 Judgement of Supreme Administrative Court in Warszawa on 1 March 2016, II OSK 36/16, CBOSA.

29 Judgment of Voivodeship Administrative Court in Gliwice on 29 September 2010, II SA/G1 354/10, CBOSA. 
Rural Development of 23 June 2004 on detailed veterinary requirements for running animal shelter ${ }^{30}$.

In light of the above stated it can be assumed that economic activity in the scope of providing care for stray animals and running animal shelters is subject to limitations which are stipulated in various acts of law. It is highly apparent in case of running an animal shelter which legal definition is stipulated by the Animal Protection Act, whereas manners of execution of such economic activity are defined by both Act on Maintaining Cleanliness, and Act on Animal Health Protection. A head or mayor of a territory where a shelter operates is the public administration body entitled to issue permission for conducting an economic activity in a form of running an animal shelter is. Simultaneously, a county veterinary inspector as a supervisory body is entitled to receive a notification of a planned commencing of a regulated activity. Additionally, requirements for conditions for running such activity are stated by regulation of a minister competent for agriculture in the scope of veterinary requirements, and a decree of a commune council - in the scope of other mandatory requirements necessary to fulfill while applying for the permission.

Applied solutions lead to a conclusion that on the grounds of the Polish law, the concept of an animal shelter has been reserved only for establishments providing care for stray animals which are organized based on regulations for a regulated activity within the meaning of the Animal Protection Act. Hence, only an establishment which has been registered by a county veterinary inspector and has been assigned an identification number is an animal shelter. Only such establishments can participate in execution of commune tasks regarding animal protection, particularly as a place of placement of caught stray animals, and as a place of mandatory sterilization or castration.

\section{Summary}

The analysis of Polish binding law acts allows one to assume that, on normative level, the obligation of public administration to provide care for

30 Journal of Laws No. 158, item 1657. 
stray animals is deeply embedded. Both the Animal Protection Act, as well as the Act on Maintaining Cleanliness, indicate the tasks of a commune in the scope of providing care for stray animals, catching homeless animals and counteracting their homelessness. Simultaneously, the analysis of jurisdiction, and inquiries as well as considerations emerging in practice of law, questions the effectiveness of applied legal solutions. The control conducted in 2013 by the Supreme Audit Office on the execution of commune obligations imposed by the Animal Protection Act showed low quality of the introduced system of providing care for stray animals ${ }^{31}$. The Supreme Audit Office negatively assessed the execution of statutory tasks regarding animal care conducted by communes and animal shelters, by which it directly indicated that communes had not been providing appropriate care for stray animals, and ineffectively counteracted their homelessness, whereas, the regulation prohibiting catching animals without providing them place shelters, had been in many cases, practically unrealizable. In the opinion of the Audit body communes, especially the smaller ones are unable to deal with the problem of animal homelessness, mostly because of lack of such establishments within their borders. Due to identified deficiencies, there is a necessity for a verification of the system of providing care for stray animals based on correction of the binding law, in the scope of:

- introducing statutory obligation of registration and earmarking of dogs,

- changing article 11a of APA by classifying the programmes of providing care for stray animals as commune public legal acts,

- enabling castration and sterilization of stray animals which are not sheltered,

- revoking provisions of article 7 of AMC in regards to protection against stray animals, and introducing into the Animal Protection Act provisions which set conditions (standards) for providing care for stray animals by communes, and conditions for issuing permissions to conduct such activities by other entities,

- updating the Animal Protection Act by adding a precise definition of an animal shelter, and by adding an entry that running a shelter is only allowed after obtaining a decision issued by county doctor

31 Information on the results of the control: Execution of commune tasks regarding animal protection, LBI-4101-13-00/2012, Item no. 46/2013/P12/193/LBI, p. 8, www.nik. gov.pl. 
of veterinary medicine which confirms fulfillment of all veterinary requirements for conducting such activity

- changing $\S 5$ item 2 point 4 of the Regulation on rules and conditions for catching stray animals, so as the following element of a contract regarding catching stray animals is made mandatory: indication of a shelter to which caught homeless animals is to be transported ${ }^{32}$.

\section{Bibliography}

Białocerkiewicz J., Status prawny zwierząt. Prawa zwierząt czy prawna ochrona zwierzat, Toruń 2005.

Biernat S., Działania wspólne w administracji państwowej, Ossolineum 1979.

Bobrowicz J., Kwalifikacja aktu normatywnego jako aktu prawa miejscowego - na przyktadzie uchwaty w sprawie programu opieki nad zwierzetami bezdomnymi $i$ zapobiegania bezdomności zwierzat, Administracja. Teoria-DydaktykaPraktyka 2012, No. 4.

Nałęcz A., Ocbrona zwierząt a postęp cywilizacyjny, in: Wptyw przemian cywilizacyjnych na prawo administracyjne $i$ administracje publiczna, eds J. Zimmermann, P.J. Suwaj, Warszawa 2013.

Radecki W., Ustawa o ochronie zwierzqt. Komentarz, Warszawa 2012.

Radecki W., Utrzymanie czystości i porządku w gminach. Komentarz, Warszawa 2012. Smaga Ł., Ocbrona humanitarna zwierzat, Białystok 2010.

Stahl M., Szczególne prawne formy dziatania administracji, in: R. Hauser, Z. Niewiadomski, A. Wróbel, System prawa administracyjnego, vol. 5, Prawne formy dziatania administracji, Warszawa 2013.

Wlaźlak K., Funkcja planowania gminy na przyktadzie programu opieki nad zwierzętami bezdomnymi oraz zapobiegania bezdomności zwierząt, Przegląd Prawa Publicznego 2015, No. 4.

\section{E-mail:}

szalewska@wp.pl 